\title{
MENINGKATKAN KEPEDULIAN ORANG TUA TERHADAP MASALAH SISWA, MELALUI KEGIATAN KUNJUNGAN RUMAH OLEH GURU BK
}

\author{
MAE ENDANG IRIASTUTI \\ SMK Negeri 1 Kalasan \\ maeprambanan@gmail.com
}

\begin{abstract}
ABSTRAK
Tugas Guru Bimbingan Konseling adalah membantu mengembangan kehidupan pribadi, sosial, belajar dan karir siswa yang sesuai dengan kebutuhan, potensi, bakat, minat dan kepribadian di satuan pendidikan. Orang tua adalah merupakan public figure dan panutan, karena pendidikan yang pertama dan utama bagi anak dalam memperoleh pembinaan moral dan penciptaan jati diri dengan cara membina, mendidik dan melatih anak sejak usia dini sampai dewasa agar dapat tumbuh dan berkembang secara optimal. Orang tua membutuhkan kerjasama dengan pihak lain, diantaranya Guru Bimbingan Konseling sebagai mitra dalam mendidik, membimbing anak menjadi pribadi yang cerdas, berpengetahuan, trampil, pandai bersosialisasi, berkarakter, dan berbudi pekerti luhur. Salah satu bentuk kerjasama dan komunikasi sekolah dengan orang tua adalah dengan melaksanakan kunjungan rumah. Literature review ini, bertujuan untuk mengumpulkan dan menganalisa serta mencari kesamaam pandangan tentang pentingnya kepedulian orang tua terhadap masalah siswa yang dapat menghambat tercapainya tujuan. Desain Literature review, menggunakan artikel dan jurnal yang terbit kurun waktu tiga tahun terakhir yaitu tahun 2018 sd 2020. Dari 5 artikel dan jurnal terpilih yang telah dianalisa didapat kesamaan hasil bahwa kepedulian orang tua terhadap masalah siswa sangat berpengaruh terhadap keberhasilan siswa.
\end{abstract}

Kata Kunci : kepedulian orang tua, masalah siswa, kunjungan rumah, guru BK.

\section{PENDAHULUAN.}

Kepedulian berasal dari kata peduli yang artinya memperhatikan, menghiraukan, mengindahkan. Kepedulian orang tua adalah perhatian orang tua. Slameto menyatakan bahwa bentuk dari kepedulian orang tua yang diberikan kepada anaknya berupa motivasi, membimbing, memperhatikan, memenuhi kebutuhan, menciptakan suasana nyaman, dan mengontrol kemajuan. Dalam melaksanakan tugasnya orang tua perlu menjalin kerjasama yang baik dengan guru di sekolah dalam hal ini Guru Bimbingan Konseling. Kerjasama tersebut untuk membangun komunikasi dalam memantau perkembangan siswa. Artinya orang tua tidak sepenuhnya memberikan tanggung jawab kepada sekolah. Untuk mengadakan komunikasi dengan orang tua dapat secara langsung maupun tidak langsung. komunikasi tidak langsung dapat dengan email, whatsup. Sedangkan komunikasi langsung dapat dengan telepon, mendatangkan orang tua atau kunjungan rumah.

Kunjungan rumah adalah upaya yang dilakukan Guru Bimbingan Konseling untuk mendeteksi kondisi keluarga dalam kaitannya dengan permasalahan siswa agar mendapat berbagai informasi yang dapat digunakan secara efektif. 
Menurut WS Winkel, (1995:76) kunjungan rumah merupakan salah satu tehnik pengumpulan data dengan jalan mengunjungi rumah siswa untuk membantu menyelesaikan masalah yang dihadapi siswa dan untuk melengkapi data siswa yang sudah ada yang diperoleh dengan tehnik lain.

Rochman Natawijaya (1979:20), menyatakan bahwa keluarga mempunyai pengaruh yang sangat besar dalam perkembangan diri individu yang dapat dilihat dari : 1) status sosial ekonomi sangat berpengaruh terhadap perilaku peserta didik, 2) keutuhan keluarga, keretakan keluarga akan memberikan pengaruh negative terhadap perkembangan kecakapan di sekolah atau tingkah laku sosialnya, 3) pola asuh otoriter, demokratis, dan atau selalu melindungi anak akan mempengaruhi perkembangan kepribadian peserta didik.

Dari beberapa pengertian diatas, dapat dikatakan bahwa kunjungan rumah merupakan upaya untuk mendeteksi kondisi keluarga dalam kaitannya dengan permasalahan siswa yang menjadi tanggung jawab pembimbing dalam pelayanan bimbingan dan konseling. Kunjungan rumah dilaksanakan apabila permasalahan yang sedang ditangani memerlukan keterangan lebih jauh tentang orang tua, kondisi keluarga dan lingkungan rumah. Hasil kunjungan rumah dapat membangun komitmen bersama antara orang tua dengan sekolah dalam mengentaskan permasalahan siswa untuk mencapai perkembangan secara optimal, melalui interaksi yang sehat dengan lingkungannya sehingga menjadi pribadi yang tangguh, mandiri dan bertanggung jawab.

Setiap orang tua mempunyai tugas dan peran yang sangat penting diantaranya : 1) melahirkan 2) mengasuh 3) membesarkan 4) mengarahkan dan mendampingi menuju kepada kedewasaan serta menanamkan norma dan nilai yang berlaku. Dalam perjalannya, orang tua dituntut untuk mampu mengembangkan potensi yang ada pada anak, memberi tauladan dan mampu mengembangkan pertumbuhan pribadinya dengan penuh tanggung jawab dan penuh kasih sayang.

Orang tua juga mempunyai fungsi dalam perkembangan siswa. Menurut Soelaeman (1987) Fungsi tersebut antara lain 1). Fungsi protektif yaitu orang tua memberikan gambaran tentang lingkungan sekitar, dengan mengarahkan perbuatan yang baik dan benar, mengajak kerjasama, dan saling membantu. 2) Fungsi sosialisasi mencakup pengembangan pribadi agar menjadi pribadi yang mantap, dan dapat menjadi anggota masyarakat yang baik.

Dari pendapat diatas, terlihat bahwa kepedulian orang tua sangatlah penting, karena sebagai pendamping pertumbuhan anak baik fisik maupun psikis dan penghubung antara anak dengan kehidupan social dan norma social yang membutuhkan fasilitas yang memadahi dan tehnik yang tepat.

Kunjungan rumah merupakan salah satu kegiatan pendukung pelayanan bimbingan konseling diantara kegiatan pendukung yang lainnya. Pelayanan bimbingan konseling di Sekolah tidak akan dapat dilaksanakan secara efektif dan dapat mencapai tujuan yang sesuai harapan tanpa didukung dengan kegiatan yang lainnya.

Tujuan Literature review ini adalah : 1). Mengumpulkan dan menganalisa serta mencari kesamaam pandangan tentang pentingnya kepedulian orang tua terhadap masalah siswa yang dapat menghambat tercapainya tujuan, 2). Memberikan kontribusi keilmuan di masa yang akan datang. 
Manfaat dari Literature review adalah lebih memahami pentingnya kunjungan rumah untuk membantu memecahkan masalah siswa dengan meningkatkan kepedulian orang tua. Mengetahui hasil penelitian yang berhubungan dan yang pernah dilaksanakan. Mengetahui metode terkini yang diusulkan untuk menyelesaikan masalah penelitian.

\section{METODE LITERATURE REVIEW.}

Desain Penelitian ini adalah Literature Review. Menurut Hasibuan, Zainal.A(2007) dalam Syafridawati (2020), Literature Review berisi ulasan, rangkuman, dan pemikiran penulis tentang beberapa sumber pustaka ( artikel, buku, slide, informasi dari internet) tentang topik yang dibahas. Literature Review tidak hanya bermaksa membaca literature, tetapi lebih kearah evalusi yang mendalam dan kritis tentang penelitian sebelumnya pada suatu topik.

Penelusuran pencarian literature dengan cara searching pada google search dan google shoolar menggunakan kata kunci. Literatur yang dipilih menggunakan artikel dan jurnal yang terbit kurun waktu tiga tahun terakhir yaitu tahun 2018 sd 2020 yang dapat diakses fulltext-pdf dengan Bahasa Indonesia. Artikel dan jurnal yang sesuai dengan kriteria inkluasi dan eksklusi diambil untuk selanjutnya dianalisis dengan mengurai kalimat kemudian dicari persamaan dan perbedaan pada masing-masing aktikel kemudian dibahas untuk dibuat kesimpulan. Kriteria inklusi literasi review dapat dilihat pada tabel berikut :

Tabel 1 . Kriteria inklusi

\begin{tabular}{|l|l|}
\hline \multicolumn{1}{|c|}{ Kriteria } & \multicolumn{1}{|c|}{ Inklusi } \\
\hline Jangka Waktu & $\begin{array}{l}\text { Penerbitan artikel dan jurnal kurun waktu 3 tahun terakhir } \\
\text { tahun 2018 sd 2020 }\end{array}$ \\
\hline Subjek & Kepedulian Orang Tua \\
\hline Bahasa & Bahasa Indonesia \\
\hline Jenis Jurnal & Artikel dan jurnal penelitian, full text pdf \\
\hline Tema & $\begin{array}{l}\text { Meningkatkan Kepedulian Orang Tua dengan Kunjungan } \\
\text { Rumah. }\end{array}$ \\
\hline
\end{tabular}

Penelusuran full text PDF

Bulan Maret 2018 - Des 2020

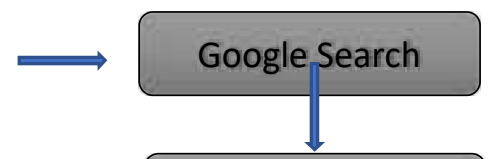

Kesesuaian dengan kriteria inkluasi $\longrightarrow$
Kesesuaian untuk dianalisa.
Gambar 1. Skema Pemilihan Artikel

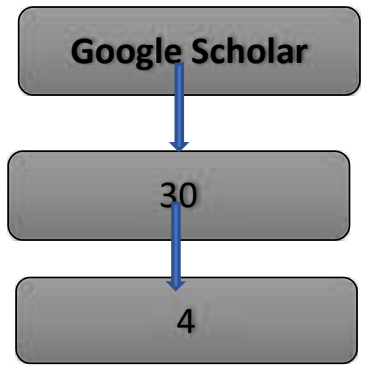


Pada Kegiatan analisis, di buat penjelasan masing-masing artikel dan jurnal, kemudian dibandingkan dan dicari persamaan dan perbedaannya lalu dibahas untuk dibuat kesimpulan.

\section{HASIL DAN PEMBAHASAN}

\begin{tabular}{|c|c|c|c|c|}
\hline Artikel & Tujuan & Metode & Sampel & Hasil \\
\hline $\begin{array}{l}\text { 1.Kepedulian } \\
\text { Orang Tua } \\
\text { Terhadap } \\
\text { Prestasi } \\
\text { Belajar } \\
\text { Anak Di Min } \\
\text { 26 Aceh Besar }\end{array}$ & $\begin{array}{l}\text { Mengetahui } \\
\text { bentukbentuk } \\
\text { kepedulian } \\
\text { orang tua } \\
\text { gampong } \\
\text { lampuja } \\
\text { terhadap prestasi } \\
\text { belajar } \\
\text { anak di MIN } 26 \\
\text { Aceh Besar }\end{array}$ & $\begin{array}{l}\text { Penelitian } \\
\text { kualitatif }\end{array}$ & $\begin{array}{l}237 \text { siswa Min } \\
26 \text { Aceh Besar }\end{array}$ & $\begin{array}{l}\text { terdapat } \\
\text { beberapa } \\
\text { bentuk } \\
\text { kepedulian } \\
\text { orang tua } \\
\text { terhadap } \\
\text { prestasi } \\
\text { belajar yaitu } \\
\text { memberikan } \\
\text { motivasi } \\
\text { belajar pada } \\
\text { anak, } \\
\text { memberikan } \\
\text { nasehat, } \\
\text { mengontrol } \\
\text { waktu belajar } \\
\text { anak, } \\
\text { memberikan } \\
\text { reward serta } \\
\text { memberikan } \\
\text { punishment. }\end{array}$ \\
\hline $\begin{array}{l}\text { 2.Hubungan } \\
\text { Kepedulian } \\
\text { Orang Tua } \\
\text { Dengan } \\
\text { Keberhasilan } \\
\text { Pendidikan } \\
\text { Anak Di } \\
\text { Jorong Labuai } \\
\text { Kecamatan } \\
\text { Koto Balingka } \\
\text { Kabupaten } \\
\text { Pasaman Barat }\end{array}$ & $\begin{array}{l}\text { Menghubungkan } \\
\text { kepedulian } \\
\text { orang tua } \\
\text { dengan } \\
\text { keberhasilan } \\
\text { pendidikan anak }\end{array}$ & $\begin{array}{l}\text { Angket atau } \\
\text { kuesioner }\end{array}$ & $\begin{array}{l}\text { Anak yang } \\
\text { putus sekolah } \\
\text { pada tingkat } \\
\text { SD, SLTP dan } \\
\text { SLTA dan } \\
\text { anak yang } \\
\text { tidak } \\
\text { melanjutkan } \\
\text { pendidikan } \\
\text { pada tingkat } \\
\text { SLTP dan } \\
\text { SLTA yang }\end{array}$ & $\begin{array}{l}\text { Berdasarkan } \\
\text { hasil } \\
\text { pengolahan } \\
\text { data terlihat } \\
\text { bahwa } \\
\text { hubungan } \\
\text { kepedulian } \\
\text { orang tua } \\
\text { dengan } \\
\text { keberhasilan } \\
\text { pendidikan } \\
\text { anak berada }\end{array}$ \\
\hline
\end{tabular}




\begin{tabular}{|c|c|c|c|c|}
\hline & & & $\begin{array}{l}\text { berusia } 13-18 \\
\text { tahun. }\end{array}$ & $\begin{array}{l}\text { pada kategori } \\
\text { kuat. }\end{array}$ \\
\hline $\begin{array}{l}\text { 3.Kajian } \\
\text { Terhadap } \\
\text { Siswa } \\
\text { Akuntansi } \\
\text { Atas Motivasi } \\
\text { Belajar, } \\
\text { Kepedulian } \\
\text { Orang Tua } \\
\text { Dan Prestasi } \\
\text { Belajar }\end{array}$ & $\begin{array}{l}\text { Untuk } \\
\text { mengetahui } \\
\text { seberapa besar } \\
\text { pengaruh } \\
\text { motivasi belajar } \\
\text { dan } \\
\text { kepedulian } \\
\text { orang tua } \\
\text { terhadap prestasi } \\
\text { belajar } \\
\text { matematika }\end{array}$ & $\begin{array}{l}\text { Survey } \\
\text { Korelasional }\end{array}$ & $\begin{array}{l}75 \text { siswa SMK } \\
\text { Amaliah } 1 \text { dan } \\
\text { SMK Amaliah }\end{array}$ & $\begin{array}{l}\text { Terdapat } \\
\text { pengaruh } \\
\text { yang } \\
\text { signifikan } \\
\text { motivasi } \\
\text { belajar dan } \\
\text { kepedulian } \\
\text { orang } \\
\text { tua secara } \\
\text { bersama-sama } \\
\text { terhadap } \\
\text { prestasi } \\
\text { belajar siswa. }\end{array}$ \\
\hline $\begin{array}{l}\text { 4. Pengaruh } \\
\text { Kepedulian } \\
\text { Orang Tua } \\
\text { Terhadap } \\
\text { Perilaku } \\
\text { Belajar Siswa } \\
\text { Kelas Vii Smp } \\
\text { Nurul } \\
\text { Hasanah } \\
\text { Tembung }\end{array}$ & $\begin{array}{l}\text { 1. Mengetahui } \\
\text { bagaimana } \\
\text { pengaruh } \\
\text { kepedulian } \\
\text { orang tua } \\
\text { terhadap } \\
\text { perilaku } \\
\text { 2. Apakah } \\
\text { kepedulian } \\
\text { orang tua } \\
\text { berpengaruh } \\
\text { terhadap } \\
\text { perilaku belajar } \\
\text { siswa } \\
\text { 3. Untuk } \\
\text { mengetahui } \\
\text { seberapa besar } \\
\text { pengaruh } \\
\text { kepedulian } \\
\text { orang tua } \\
\text { terhadap } \\
\text { perilaku belajar } \\
\text { siswa }\end{array}$ & $\begin{array}{l}\text { Kuantitatif } \\
\text { deskriptif }\end{array}$ & $\begin{array}{l}30 \text { dari } 119 \\
\text { Siswa kelas } \\
\text { VII SMP } \\
\text { Nurul } \\
\text { Hasanah }\end{array}$ & $\begin{array}{l}\text { Terdapat } \\
\text { pengaruh } \\
\text { yang positif } \\
\text { kepedulian } \\
\text { orang tua } \\
\text { terhadap } \\
\text { perilaku } \\
\text { belajar siswa. }\end{array}$ \\
\hline
\end{tabular}




\begin{tabular}{|c|c|c|c|c|}
\hline $\begin{array}{l}\text { 5.Gambaran } \\
\text { Kepedulian } \\
\text { Orang Tua } \\
\text { Terhadap } \\
\text { Pendidikan } \\
\text { Remaja Di } \\
\text { Jorong Sungai } \\
\text { Cubadak } \\
\text { Kecamatan } \\
\text { Akabiluru } \\
\text { Kabupaten } \\
\text { Lima Puluh } \\
\text { Kota }\end{array}$ & $\begin{array}{l}\text { Menganalisis } \\
\text { atau } \\
\text { memaparkan } \\
\text { keadaan, } \\
\text { kondisi, situasi, } \\
\text { kejadian dan } \\
\text { menghasilkan } \\
\text { paparan berupa } \\
\text { laporan } \\
\text { penelitian. }\end{array}$ & $\begin{array}{l}\text { Penelitian } \\
\text { deskriptif }\end{array}$ & $\begin{array}{l}\text { Remaja usia } \\
13 \text { sd } 21 \text { tahun } \\
\text { yang } \\
\text { berjumlah } 47 \\
\text { orang. }\end{array}$ & $\begin{array}{l}\text { Gambaran } \\
\text { kepedulian } \\
\text { orang tua } \\
\text { terhadap } \\
\text { pendidikan } \\
\text { remaja dalam } \\
\text { memenuhi } \\
\text { kebutuhan, } \\
\text { memberi } \\
\text { motivasi, dan } \\
\text { mengawasi } \\
\text { sangat tinggi, }\end{array}$ \\
\hline
\end{tabular}

Pada artikel penelitian nomor 1. ditemukan terdapat beberapa bentuk kepedulian orang tua terhadap prestasi belajar. Yaitu memberikan motivasi belajar pada anak, memberikan nasehat, mengontrol waktu belajar anak, memberikan reward serta memberikan punishment. Hal- hal yang demikian tidak hanya dilakukan oleh orang tua saja, namun pihak sekolah seperti kepala sekolah dan guru, guru bimbingan konseling juga ikut berperan untuk mendorong siswa memperoleh prestasi yang baik.

Pada artikel penelitian nomor 2. Berdasarkan hasil penelitian ini dapat disimpulkan bahwa kepedulian orang tua terhadap anak ada hubungammya dengan keberhasilah pendidikan. Semakin tinggi kepedulian orang tua maka keberhasilan pendidikan semakin tinggi pula. Berdasarkan hasil pengolahan data terlihat bahwa hubunagan kepedulian orang tua dengan keberhasilan pendidikan berada pada kategori kuat. Dengan simpulan semakin tinggi kepedulian orang tua terhadap anak maka akan semakin tinggi tingkat keberhasilan pendidikan, maka diperlukanya kerjasama antara sekolah dengan orang tua.

Pada artikel penelitian nomor 3. Kepedulian orang tua dan motivasi secara bersama-sama berpengaruh terhadap prestasi belajar. Orang tua sebagai pengasuh, pembimbing, pemelihara dan sebagai pendidik anak dengan harapan anak menjadi pandai, cerdas dan berahlak.

Pada artikel penelitian nomor 4. Menunjukkan bahwa kepedulian orang tua memiliki kontribusi dalam meningkatkan perilaku belajar siswa, sehingga siswa yang mendapatkan kepedulian orang tuanya baik, akan memiliki perilaku belajar yang baik dan sebaliknya jika siswa kurang mendapatkan kepedulian orang tua dengan baik maka akan memiliki perilaku yang kurang baik.

Pada artikel penelitian nomor 5. Hasil penelitian didapat dari gambaran kepedulian orang tua terhadap pendidikan remaja dalam memenuhi kebutuhan, memotivasi, mengawasi, dan membimbing adalah sangat tinggi, hal ini berarti sebagian besar orang tua peduli terhadap pendidikan remaja yaitu dengan memenuhi kebutuhannya baik fisik maupun psikis. Kebutuhan tersebut diantaranya memberikan motivasi, mengawasi dan membimbing. 
Dari uraian hasil ke lima penelitian diatas terdapat perbedaan diantaranya metode penelitian yang digunakan, sehingga mempengaruhi hasil penelitian. Subyek yang diteliti untuk penelitian 1 menggunakan seluruh siswa/ populasi, sedangkan penelitian 2,3,4 dan 5 masing-masing menggunakan sample. Hasil penelitian 1 menunjukkan beberapa bentuk kepedulian orang tua, penelitian 2 menunjukkan hubungan kepedulian orang tua, penelitian 3 dan 4 menunjukkan pengaruh kepedulian orang tua dan penelitian 5 menunjukkan hasil gambaran kepedulian orang tua sangatlah penting.

Persamaan yang dapat ditemukan dari literature review terhadap ke lima artikel dan jurnal tersebut adalah bahwa kepedulian orang tua mempengaruhi kondisi siswa baik motivasi, perilaku, dan perkembangan siswa yang berkaitan dengan keberhasilan siswa. Beberapa factor yang diduga dapat mempengaruhi keberhasilan selain kepedulian orang tua adalah minat dan semangat siswa. Kepedulian orang tua terhadap anak sangat penting untuk membantu memulihkan sikap spikologi anak.

Dari hasil analisis ke lima penelitian di atas, dengan persamaan hasil bahwa terdapat pengaruh yang signifikan antara kepedulian orang tua terhadap kondisi siswa. Kepedulian dalam kamus bahasa Indonesia (Depdikbud,1991 ) diartikan sebagai prihal sangat peduli, sikap mengindahkan. Kepedulian orang tua terhadap pendidikan anak di sekolah adalah perhatian yang ditunjukan oleh orang tua kepada anak dalam proses belajarnya di sekolah berupa pemberian bantuan, bimbingan dan pengaruh agar kegiatan belajar siswa di sekolah dapat berlangsung dengan baik

Siswa dapat belajar dengan baik jika tidak terdapat kendala yang menghambatnya. Disinilah diperlukannya komunikasi dan kerjasama antara sekolah dengan orang tua. Salah satu bentuk komunikasi dan kerjasama itu adalah dengan melaksanakan kunjungan rumah.

Menurut Yusuf Gunawan (1992-237), perlunya dilaksanakan kunjungan rumah adalah : 1) jika permasalahan yang dihadapi siswa berkaitan dengan masalah kluarga. 2) Keluarga sebagai salah satu sumber data yang lengkap dan akurat. 3) Dalam pelayanan bimbingan dan konseling perlu kerjasama untuk membangun komitmen antara keluarga dan atau orang tua dengan sekolah. 4) Faktor situasi dan kondisi keluarga maupun pola asuh orang tua memegang peranan penting terhadap perkembangan kesejahteraan peserta didik.

Sejalan dengan ini Thantawi (1995:47) menyatakan tujuan kunjungan rumah bertujuan, 1). Menambah kelengkapan data atau informasi tentang siswa melalui wawancara dengan orang tua dan observasi suasana rumah siswa. 2) memberi penjelasan tentang keadaan siswa kepada orang tua untuk membangun kerja sama antara sekolah dengan keluarga. 3) meningkatkan tingkat kepedulian orang tua terhadap masalah yang dihadapi oleh siswa.

Dari pendapat-pendatap di atas dapat diketahui bahwa pelaksanaan kunjungan rumah mempunyai tujuan sebagai berikut :

1. Memperoleh data siswa secara lengkap dan akurat yang berkaitan dengan orang tua, keluarga dan lingkungannya.

2. Dapat menyampaikan atau mengadakan komunikasi dan koordinasi kepada orang tua tentang permasalahan yang dihadapi oleh siswa. 
3. Memahami dan mengetahui secara langsung tentang pola asuh yang diterapkan oleh orang tua terhadap siswa.

4. Sebagai sarana kerjasama untuk membangun komitmen bersama antara keluarga atau orang tua dengan sekolah terhadap penanganan masalah siswa.

5. Sebagai sarana untuk mencari dan menentukan solusi atau pemecahan terhadap penanganan masalah siswa secara tepat.

6. Meningkatkan tingkat kepedulian orang tua terhadap masalah yang dihadapi oleh siswa.

\section{SIMPULAN.}

Berdasarkan hasil ke lima literature review dari artikel dan jurnal diatas adalah bahwa kepedulian orang tua mempengaruhi kondisi siswa baik motivasi, perilaku, dan perkembangan siswa yang berkaitan dengan keberhasilan siswa. Kepedulian orang tua terhadap anak sangatlah penting karena dapat membantu untuk menjaga dan memulihkan sikap spikologi anak. Sehubungan dengan pendidikan anak di sekolah, maka tanggung jawab pendidikan tidak hanya pada guru, tetapi juga pada orang tua dalam membantu membimbing, mengarahkan untuk mencapai tujuan pendidikan. Oleh karena itu keberhasilan pendidikan di sekolah sangat ditentukan oleh kepedulian orang tua. Sehingga dibutuhkan komunikasi dan kerjasama antara sekolah dengan orang tua. Salah satu bentuk komunikasi dan kerjasama itu adalah dengan melaksanakan kunjungan rumah.

Dalam pelaksanaan kunjungan rumah tahapan yang harus dilalui meliputi : kegiatan perencaan, pelaksanaan, evaluasi, analisis hasil evaluasi, tindak lanjut dan pelaporan yang dipake sabagai pendukung pelayanan bimbingan konseling selanjutnya.

\section{DAFTAR PUSTAKA}

Ahmad Didad, 2020, “ Kepedulian Orang Tua Terhadap Prestasi Belajar Anak Di Min 26 Aceh Besar" Skripsi, Darussalam-Banda Aceh, Universitas Islam Negeri Ar-Raniry.

Akhmad Farid Mawardi Sufyan, 2018," Bina Madrasah, Upaya Peningkatan

Kepedulian Orang Tua/Wali Murid Terhadap Perkembangan Putra-Putri Anak Didik Madrasah” Skripsi, Madura, Universitas Islam Madura

BP BK SMP. 2016,"KUNJUNGAN PADA RUMAH (Home Visit)" https://bimbingan konselingsiswasmp.blogspot.com/2016/09/kunjungan-,pada-rumah-homevisit.html, diakses pada September 2016.

Cut Nya Dhin, 2020, "Kepedulian Orang Tua Terhadap Pendidikan Agama Siswa" Jurnal Kinerja Kependidikan, Banda Aceh, Universitas Islam Negeri Ar-Raniry Banda Aceh.

Fahriati, 2018," Hubungan Kepedulian Orang Tua Dengan Keberhasilan Pendidikan Anak Di Jorong Labuai Kecamatan Koto Balingka Kabupaten Pasaman Barat” Jurnal Pendidikan, Padang, Universitas Negeri Padang 
Latifah Hanum, 2019 “ Pengaruh Kepedulian Orang Tua Terhadap Perilaku Belajar Siswa Kelas Vii Smp Nurul Hasanah Tembung” Skripsi, Medan, Universitas Negeri Sumatra Utara.

Prayitno, 2012 “Jenis Layanan Dan Kegiatan Pendukung Konselin” Padang : PPK BK.

Ronal Maruli Tua Manurung, 2017, "Kepedulian Orang Tua Terhadap Masa Depan Pendidikan Anak Di Desa Bandar Tengah Kecamatan Bandar Khalifah Kabupaten Serdang Bedagai", Skripsi, Medan, Universitas Negeri Medan.

Siska Manda Sari1, Afrizal Sano2, Indah Sukmawati, 2013 "Hambatan yang dialami oleh guru BK dalam pelaksanaan kegiatan kunjungan rumah di SMP dan SMA Negeri Kota Payah Kumbuh - Jurnal Ilmiah Konseling-(hlm 59 - 61).

Thantawy 1995 “ Manajemen Bimbingan dan Konseling ”, Jakarta, PT Pamator Presisindo.

Yelvina, 2018 "Gambaran Kepedulian Orang Tua terhadap Pendidikan Remaja Di Jorong Sungai Cubadak Kecamatan Akabiluru Kabupaten Lima Puluh Kota”, Jurnal Pendidikan, Padang, Universitas Negeri Padang.

Yusuf Gunawan, 1992 "Pengantar Bimbingan dan Konseling", Jakarta, PT Gramedia. Y.Triwidatin, 2018," Kajian Terhadap Siswa Akuntansi Atas Motivasi Belajar, Kepedulian Orang Tua Dan Prestasi Belajar", Jurnal, Bogor, Universitas Djuanda Bogor. 